\title{
Upper secondary education for youth at risk: A comparative analysis of education and training programmes in Austria, Norway, Sweden and Switzerland
}

\author{
Evi Schmid* \\ OsloMet - Oslo Metropolitan University, Department of Vocational Teacher Education, Oslo
}

Received 20.03.2019, Accepted 13.09.2019, Published: 29.04.2020

\begin{abstract}
Context: Vocational education and training (VET) plays a key role in reducing early leaving from education and training, and integrating youth at risk in upper secondary education. To ensure that more young people complete upper secondary education, the OECD suggests designing interventions that address the specific needs of youth at risk such as changes in the standard duration, preparatory programmes or personalised support measures. Based on a comparative analysis of such programmes tailored to the needs of youth at risk in Austria, Norway, Sweden and Switzerland, the objective of this article is to identify the different education and training models these countries employ to include youth at risk in upper secondary education.
\end{abstract}

Approach: The study is based on document analysis; the documents studied are public documents such as law texts and white papers from the education authorities as well as research publications. The interventions proposed by the OECD to adapt training programmes to the specific needs of youth at risk were chosen as a basis for the comparative analysis. Further structural characteristics of the programmes complemented the analysis.

Findings: The study found four different types of education and training models for youth at risk in Austria, Norway, Sweden and Switzerland: Short-track (Norway, Switzerland), prolonged (Austria), individualised (Austria, Norway and Sweden) and preparatory program-

Corresponding author: evis@oslomet.no 
mes (Sweden). Preparatory and prolonged programmes aim to help young people to achieve upper secondary qualifications through preparatory measures, more time or more support. Individualised or short-track programmes aim to adapt education and training programmes to young people's needs by reducing the programmes' demands. In all four countries, young people have the opportunity to conclude their education with a certificate at a level lower than 'regular' upper secondary education.

Conclusion: The four countries surveyed differ widely in terms of educational traditions and the position of VET at upper secondary level. Regarding the integration of disadvantaged youth into education and work, the differences concerning access to upper secondary education, the importance of VET at upper secondary level and the recognition of training programmes for youth at risk may be of particular relevance. Further research is needed to empirically investigate the effectiveness of the identified education and training models as a means of integrating youth at risk into upper secondary education.

Keywords: VET, vocational education and training, dropout, youth at risk, social inclusion, comparative analysis

\section{Introduction}

Early leaving from education and training is linked to unemployment, social exclusion and poverty. Combating early school leaving has been a priority for the European Union since 2000, and its current aim is to reduce dropout to below 10 percent by 2020 (European Parliament, 2011). As VET is presented as both a means of preventing early school leaving and a safety net for those who drop out of general education (Cedefop, 2016), it will play a key role in achieving this goal. Current figures show that, on average, 19 percent of people under 25 across OECD countries and the EU leave education without an upper secondary qualification (OECD, 2018a). Although most of the countries have a long way to go to reach the EU's goal, most of them ensure the majority of young people achieve an upper secondary qualification. However, the education system fails a small group of young people in every country by not providing adequate programmes to enable them to complete upper secondary education (Markussen, 2011). This group varies from 10 to 40 percent in most countries.

In every country, issues relating to the inclusion of potentially marginalised young people will make requirements of how diversity is handled. In order to ensure that more young people complete upper secondary education, the system must include young people with different preconditions, needs, abilities and wishes. Getting more young people at potential risk to continue and complete upper secondary education places a great deal of pressure on the flexibility and institutional structures of the education system (Hoffman, 2011; Lamb \& Markus- 
sen, 2011). This applies in particular to VET, which has to educate a far more educationally and socially differentiated target group than previously (Larsen \& Persson Thunqvist, 2018).

This article focuses on young people who are most at risk of dropping out of upper secondary education without achieving qualifications at this level. Based on the different practices in Austria, Norway, Sweden and Switzerland, the objective of this article is to identify the strategies these countries employ to adapt upper secondary level education to youth at risk.

\section{Background and literature review}

Early school leaving is a result of the interplay of multiple risk factors linked to both the individual and the system. Based on individual and social characteristics, dropout is defined as the culmination of a long and problematic school career. Dropout is not thus a one-off event, but the result of a long process of low engagement in schooling. In the international research literature, there is a strong consensus regarding the factors that affect this process and thus the probability of young people leaving school before completion. These factors can be summarised as follows: 1) individual background characteristics such as gender, ethnicity or health; 2) social background characteristics such as family context, peers and networks; 3 ) institutional characteristics such as school structures, school and classroom climate as well as policy settings; and 4) personal dispositions such as the students' engagement, aspirations and achievements (Cedefop, 2016; Lamb, 2011c; Rumberger, 2011).

A lot of research shows that socially disadvantaged youth represent a particular risk group. Young people from disadvantaged social backgrounds and young people with migrant backgrounds have an increased risk of not completing upper secondary education (Archambault et al., 2017; Lamb, 2011c; Rinne \& Järvinen, 2011; Rumberger, 2011). In addition, in many countries, boys are more likely to leave education early than girls (Jørgensen, 2015; Traag \& van der Velden, 2011). Furthermore, young people with health problems have a higher risk of leaving school before completion (De Ridder et al., 2013; Quiroga, Janosz, Bisset \& Morin, 2013).

In addition to individual and social background factors, research has identified poor educational outcomes as one of the strongest predictors of early school leaving (Janosz et al., 2011; Lamb, 2011b; Rumberger, 2011). However, as already mentioned, it is important to emphasise that the various risk factors are interrelated and affect each other, and socioeconomic disadvantage and educational disadvantage are particularly closely interrelated. Research shows that social background factors such as parents' education and labour market status, their attitude to education and their support, have a major impact on how students identify with school, their engagement and ambitions (Alexander et al., 2001; Finn, 1989; Rumberger \& Rotermund, 2012). Young people who do not complete upper secondary education thereby constitute a particularly vulnerable group. They are often socially disadvan- 
taged and lack social resources such as support and networks, they often have a long and difficult school career behind them, many have performed poorly and have had a low sense of mastery over time, and many struggle with learning difficulties and social and mental health challenges.

At a political level, VET is recognised as playing a key role in combating early leaving from education and training (Cedefop, 2016; European Commission, 2014). There are several reasons why efforts to reduce early school leaving especially applies to VET: for one thing, VET shows higher dropout rates than general education in many countries. One of the reasons for this is the selectiveness of education systems, which tend to direct those who are at greater risk of early school leaving towards VET. In most countries, VET hosts a much larger share of students from disadvantaged backgrounds. Other reasons may be the perceived quality or the attractiveness of VET programmes which for many young people are considered a second choice (Cedefop, 2016; European Commission, 2014). However, the important role of VET in preventing early school leaving is not only related to reducing dropout from VET, but also to its potential to attract and reintegrate young people in education and training, including those who drop out of general education (Cedefop, 2016; European Commission, 2014). For many young people, VET may constitute a positive alternative to general education. It offers a more practical way of learning and the opportunity to work towards a specific profession. Moreover, vocational courses represent a community of practice, which the students recognise and value, and where their previous knowledge is recognised (Korp, 2012).

Research confirms that VET plays an important role with respect to the inclusion of youth at risk. A number of studies show that the percentage of young people in VET programmes has a positive effect on the upper secondary education completion rate (e.g. De Witte et al., 2013; Lamb, 2011a; Lavrijsen \& Nicaise, 2015). A well-developed range of VET programmes thus appears to increase the level of completion by acting as a 'safety net against dropout' (Lavrijsen \& Nicaise, 2015, p. 307) for less academically-oriented young people. However, youth at risk may struggle to gain access to upper secondary education training places. In school-based systems, access to the programmes may be regulated by admission requirements based on grades from lower secondary school or entry exams. Low-achieving youth who do not meet these goals may thus not gain a place in upper secondary education or be at the back of the queue when it comes to choosing programmes. Young people who suffer from low motivation and learning difficulties thus risk being placed in programmes they are not interested in, and research shows that not getting in to your first choice is a risk factor in relation to completing upper secondary education (Markussen et al., 2008).

Finding an apprenticeship place in apprenticeship-based systems can also be a challenge for youth at risk. Research shows that socially and educationally disadvantaged youth encounter difficulties in gaining apprenticeship places (e.g. Hupka-Brunner et al., 2010; Solga \& Kohlrausch, 2013). The reasons for this may be diverse: Firstly, youth with low skills tend 
to need more instruction time and may be less productive at work. Taking on a young person at risk as an apprentice is thus costlier for employers (OECD, 2018b). Moreover, youth from disadvantaged families often lack a relevant social network with respect to careers of interest. Finally, research shows that disadvantaged youth and especially those with migrant backgrounds face the risk of discrimination when applying for an apprenticeship place (Imdorf, 2017).

To ease the transition into apprenticeship training and to help youth at risk complete upper secondary education, the OECD (2018b) suggests designing interventions that address the specific needs of youth at risk that are also attractive to employers. These include changes in the standard duration - either shorter or longer than normal -, preparatory programmes or personalised support measures to tackle the problems apprentices face during apprenticeships (OECD, 2018b). Such programmes tailored to the needs of youth at risk, both in apprenticeship-based and school-based VET systems, are the focus of this paper.

\section{Data and method}

Comparative studies contribute to social science by identifying common challenges and different ways of dealing with them. Interest in comparative studies has increased in recent decades, including in VET. However, the range of VET programmes available to youth at risk has not been the focus of comparative research to any extent. Therefore, the study aims to expand the research focus on this area of upper secondary education. Four countries were selected - Austria, Norway, Sweden and Switzerland -, and the study describes the range of programmes available to youth at risk in these countries. Based on the recommendations of the OECD (2018b) to adapt upper secondary education programmes to the abilities and needs of youth at risk, the aim is to identify strategies which these countries apply and to identify different education and training models for youth at risk. The study addresses thus the following research question:

What education and training models do Austria, Norway, Sweden and Switzerland employ to include youth at risk in upper secondary education?

The educational programmes included in the study are at upper secondary level, programmes in the transition between lower and upper secondary education are not included. Programmes at a regional or school level are also not included, the study focuses only national programmes.

Given that the study aims to identify different education models for youth at risk, it is natural to choose countries with different training traditions (Busemeyer \& Trampusch, 2012). Austria and Switzerland were chosen as two examples of apprenticeship-based systems, where business and industry and their organisations play an important role, and where training 
is alternately conducted in a company and at a school. In both countries, about two thirds of young people at upper secondary level enrol in vocational programmes. These two countries are thus among the countries with the highest proportion of young people in VET programmes at upper secondary level across OECD countries and the EU (OECD, 2018a). In Switzerland, the vast majority of them enrol in apprenticeship-based programmes, whereas in Austria combined school and work-based, and school-based programmes make up roughly equal parts (see table 1). Sweden was chosen as an example of a school-based training model, where VET is an integral part of the general school system and is largely conducted at school. Compared to Austria and Switzerland, VET in Sweden has a significantly weaker position at upper secondary level with only 37 percent of young people enrolling in vocational programmes (OECD, 2018a; see table 1). In contrast to Austria and Switzerland, it has been a priority in Sweden to provide all young people with access to higher education in an integrated, fulltime upper secondary school, while giving low priority to work-based learning of vocational skills (Jørgensen, 2018).

Norway's model, with two years of school-based preparation followed by a two-year apprenticeship, has characteristics common to both apprenticeship-based and school-based models (Nyen \& Tønder, 2015). Half of all young people at upper secondary level enrol in vocational programmes. However, due to dropout and students changing from VET to general education programmes, the proportion of young people in apprenticeship training in the third year is much lower (OCED, 2018a; see table 1).

Furthermore, according to an American study, Austria, Norway and Switzerland are among the six best countries in the world with respect to VET (Hoffman, 2011), while Norway and Sweden are highlighted as having a high degree of inclusive training at school (OECD, 2013).

The study is based on document analysis. According to Bowen (2009, p. 29), document analysis 'is particularly applicable to qualitative case studies - intensive studies producing rich descriptions of a single phenomenon, event, organisation, or program'. The cases of interest in this study are countries, or more specifically education and training programmes in four countries. The documents studied are primarily law texts and white papers from the education authorities. Public documents are shaped by the political context in which they are produced and reflect thus the state's interests (Scott, 1990). This information is supplemented with relevant figures from research publications. Based on the information about the programmes available to youth at risk, a table containing structural characteristics was developed. The structural characteristics to be examined were defined on the basis of the interventions proposed by the OECD (2018b), which include the length of the programme and whether they include personalised support measures or not. These characteristics were supplemented by other characteristics which proved to be essential while analysing the documents: admission requirements, standardised training plans and standardised final tests, 
separate professional titles, number of different programmes/professions and whether the programme counts as completion of upper secondary education or not. Finally, statistical information on the percentage of a year group in the programmes, the rate of upper secondary completion, the percentage of students in VET programmes at upper secondary level and the percentage of students in combined school and work-based VET was added. The table forms the basis for comparing the practices in the different countries and for identifying different education and training models (see table 1).

\section{$4 \quad$ Results: Education and training programmes available to youth at risk in Austria, Norway, Sweden and Switzerland}

The study found seven different training schemes at national level for youth at risk in Austria, Norway, Sweden and Switzerland: A prolonged apprenticeship scheme and a partial qualification scheme in Austria, a training candidate scheme and a training practice certificate scheme in Norway, the introduction programme in Sweden, which consists of four different programmes, one of them being vocational introduction, and two-year apprenticeships with Federal VET Certificate in Switzerland. The following table 1 gives an overview of the investigated characteristics of these education and training programmes. A description of each of the programmes follows in the following subchapters on the individual countries. 
Table: Structural features of education and training programmes for youth at risk in Austria, Norway, Sweden and Switzerland

\begin{tabular}{|c|c|c|c|c|}
\hline & Austria & Norway & Sweden & Switzerland \\
\hline $\begin{array}{l}\text { Name of the training scheme (in } \\
\text { the language of the country) }\end{array}$ & $\begin{array}{l}\text { 1) Lehrausbildung in verlängerter } \\
\text { Lehrzeit gem. 8b Abs. } 1 \text { BAG } \\
\text { 2) Teilqualifikation gem. 8b Abs. } \\
\text { 2 BAG }\end{array}$ & $\begin{array}{l}\text { 1) Lærekandidatordning } \\
\text { 2) Praksisbrevordning }\end{array}$ & $\begin{array}{l}\text { 1) Introduktionsprogram } \\
\text { 2) Yrkesintroduktion }\end{array}$ & $\begin{array}{l}\text { Zweijährige berufliche Grund- } \\
\text { bildung mit eidgenössischem } \\
\text { Berufsattest EBA }\end{array}$ \\
\hline $\begin{array}{l}\text { Name of the training scheme in } \\
\text { English }\end{array}$ & $\begin{array}{l}\text { 1) Prolonged apprenticeship } \\
\text { scheme } \\
\text { 2) Partial qualification scheme }\end{array}$ & $\begin{array}{l}\text { 1) Training candidate scheme } \\
\text { 2) Training practice certificate } \\
\text { scheme }\end{array}$ & $\begin{array}{l}\text { 1) Introduction programme ( } 4 \\
\text { programmes) } \\
\text { 2) Vocational introduction ( } 1 \text { of } \\
\text { the programmes under } 1 \text { ) }\end{array}$ & $\begin{array}{l}\text { Two-year apprenticeship with } \\
\text { Federal VET Certificate }\end{array}$ \\
\hline $\begin{array}{l}\text { Percentage of a year group in } \\
\text { the programme(s) }\end{array}$ & $3 \%$ & $2.1 \%$ & $\begin{array}{l}\text { 1) } 24.8 \% \text { in the first year, } 17.5 \% \\
\text { of all the students in upper secon- } \\
\text { dary education (all programmes) } \\
\text { 2) } 1.9 \% \text { of all the students in } \\
\text { upper secondary education }\end{array}$ & $5.9 \%$ \\
\hline Admission requirements & $\begin{array}{l}\text { 1) Yes } \\
\text { 2) Yes }\end{array}$ & $\begin{array}{l}\text { 1) No } \\
\text { 2) No } \\
\end{array}$ & $\begin{array}{l}\text { 1) No (in } 3 \text { of } 4 \text { programmes) } \\
\text { 2) No }\end{array}$ & No \\
\hline Length of training & $\begin{array}{l}\text { 1) } 3-6 \text { years } \\
\text { 2) } 1-3 \text { years }\end{array}$ & $\begin{array}{l}\text { 1) } 1-4 \text { years, usually follows the } \\
2+2 \text {-model } \\
\text { 2) } 2 \text { years }\end{array}$ & $\begin{array}{l}\text { 1) Not defined at the national } \\
\text { level, usually } 1-3 \text { years } \\
\text { 2) Not defined at the national } \\
\text { level, at most schools } 3 \text { years }\end{array}$ & 2 years \\
\hline $\begin{array}{l}\text { Standardised training plans and } \\
\text { final test }\end{array}$ & \begin{tabular}{|l} 
1) Yes \\
2) No
\end{tabular} & $\begin{array}{l}\text { 1) No } \\
\text { 2) Yes }\end{array}$ & $\begin{array}{l}\text { 1) No } \\
\text { 2) No }\end{array}$ & Yes \\
\hline $\begin{array}{l}\text { Personalised support } \\
\text { measures }\end{array}$ & $\begin{array}{l}\text { 1) Yes } \\
\text { 2) Yes }\end{array}$ & $\begin{array}{l}\text { 1) } \mathrm{No} \\
\text { 2) } \mathrm{No}\end{array}$ & $\begin{array}{l}\text { 1) No } \\
\text { 2) No }\end{array}$ & Yes \\
\hline
\end{tabular}




\begin{tabular}{|c|c|c|c|c|}
\hline Separate professional titles & $\begin{array}{l}\text { 1) Concludes with a trade certi- } \\
\text { ficate } \\
\text { 2) No }\end{array}$ & $\begin{array}{l}\text { 1) No } \\
\text { 2) No }\end{array}$ & $\begin{array}{l}\text { 1) No } \\
\text { 2) No }\end{array}$ & Yes \\
\hline $\begin{array}{l}\text { Number of different } \\
\text { programmes/ professions }\end{array}$ & Approx. 200 & $\begin{array}{l}\text { 1) Possible for all education } \\
\text { programmes and approx. } 200 \\
\text { recognised trades } \\
\text { 2) All the county authorities shall } \\
\text { have at least one training practice } \\
\text { certificate programme }\end{array}$ & $\begin{array}{l}\text { 1) } 4 \\
\text { 2) Possible for all vocational } \\
\text { programmes }\end{array}$ & Approx. 57 \\
\hline $\begin{array}{l}\text { Does the programme count as } \\
\text { completion of upper } \\
\text { secondary education? }\end{array}$ & $\begin{array}{l}\text { 1) Yes } \\
\text { 2) No }\end{array}$ & $\begin{array}{l}\text { 1) No } \\
\text { 2) No }\end{array}$ & $\begin{array}{l}\text { 1) No } \\
\text { 2) No }\end{array}$ & Yes \\
\hline $\begin{array}{l}\text { Upper secondary completion } \\
\text { rate (2016) (OECD, 2018a; BFS, } \\
\text { 2018a) }\end{array}$ & $80.56 \%$ & $80.16 \%$ & $77.43 \%$ & $90.90 \%$ \\
\hline $\begin{array}{l}\text { Percentage of students in VET } \\
\text { programmes at upper secondary } \\
\text { level }(2016)(\text { OECD, 2018a) }\end{array}$ & $69 \%$ & $50 \%$ & $37 \%$ & $65 \%$ \\
\hline $\begin{array}{l}\text { Percentage of students in com- } \\
\text { bined school and work-based } \\
\text { VET (2016) (OECD, 2018a) }\end{array}$ & $32 \%$ & $17 \%$ & $2 \%$ & $58 \%$ \\
\hline
\end{tabular}




\subsection{Austria}

In 2003, Austria introduced two types of schemes for youth at risk: a prolonged apprenticeship scheme and a partial qualification scheme. They target learners with special needs, people with disabilities, those without a basic school-leaving certificate and youth who are difficult to place in training companies (Section $\$ 8 \mathrm{~b}$ of the Austrian Vocational Training Act). These two schemes account for more than six percent of apprentices in VET. This corresponds to about three percent of a year group (Dornmayr, 2017).

Apprentices in a prolonged apprenticeship scheme follow the same competence goals as apprentices in 'regular' programmes, and take the same trade or journeyman's certificate. However, training is normally extended by one, or, in some cases, two years, making the training pathway between three and six years. These apprentices are also entitled to a "vocational assistant" who follows and guides them throughout their education. The goal of this training pathway is thus to offer young people with special needs a full VET by giving them more time and support (Dornmayr, 2017). Apprentices in the partial qualification pathway follow individualised curricula. A training contract defines the competence goals, selected from a pathway towards a full vocational qualification. The training has a duration of between one and three years and concludes with an individual competence test. These young people are also entitled to a "vocational assistant" (Section $\$ 8 \mathrm{~b}$ of the Austrian Vocational Training Act).

Both VET in the form of a prolonged apprenticeship and pathway towards partial competence are mainly practice-based pathways with training taking place both at school and in a company or training institution. The majority of young people are trained in private apprenticeship companies (Dornmayr, 2017). These young people generally join regular classes at school. Both schemes can be implemented in each of the around 200 vocations on offer in Austria (Heckl et al., 2008).

Around half of the apprentices who undergo training in a prolonged apprenticeship or in a partial competence pathway, complete the training and pass the final test. The dropout rate is thus higher for these pathways than for apprenticeships in general (Dornmayr et al., 2017). Three years after the completion of training, 67 percent of those who completed a prolonged apprenticeship, and 56 percent of those who took a partial competence pathway, were in employment. Labour market integration is thus more difficult for these young people than for VET graduates in general, but the employment rate is significantly higher than for those who dropped out of education (Dornmayr, 2017).

VET for young people with special needs provided through these two schemes is considered a success: The young people receive a formal diploma, a trade certificate or a vocational training certificate, gain the possibility for individualisation and close follow-up, at the same time as they have the greatest possible freedom of choice (Heckl et al., 2008). Defined admission criteria also ensure that these education pathways do not replace but rather supplement regular pathways (Dornmayr, 2017). 


\subsection{Norway}

Upper secondary education in Norway comprises five general education and eight vocational programmes ${ }^{1}$ that either lead to a university admissions certification or a trade- or journeyman's certificate. The reform of 1994 also introduced a third form of competence known as "documented partial competence" (Section 3-3 of the Norwegian Education Act). Documented partial competence is competence that is at a lower level than full vocational or university admissions certification, and can be achieved by completing a training candidate or a training practice certificate scheme (Vilbli, 2018).

The training candidate scheme became statutory in 2001. The target group is youth "who wish to take upper secondary education and training in a company but are unable to meet the requirements of a trade and journeyman's certificate" (Utdanningsdirektoratet, 2015, p. 1). An individual training plan is based on the individual's needs, in which the training candidate's wishes and abilities are emphasised. There are no requirements of subjects or the number of competence goals, and the duration of the apprenticeship can vary from one to four years. The training generally follows the $2+2$ model, where two years at school are followed by two years in a company. The training candidate's training plan forms the basis for the individual competence test, which is less comprehensive than a regular trade or journeyman's certificate (Section 4-1 of the Norwegian Education Act).

The training practice certificate scheme was introduced in 2016 following a trial period of several years in various counties. The target group is youth "who may have poor grades, high school-absence, but who do not have learning difficulties or special training needs, and who are assumed to be able to reach the competence goals over time through more practical training in a company" (Utdanningsdirektoratet, 2017, p 1). The pathway is two years, and the majority of the education and training takes place in a company. Unlike the training candidate scheme, the training practice certificate scheme is not individually adapted, but based on a common local curriculum that comprises a range of competence goals from the corresponding national education programme. Full goal achievement is also required in the common core subjects Norwegian, mathematics and social studies. After two years, the training practice certificate candidates take a standardised training practice certificate test (Utdanningsdirektoratet, 2017).

Training candidates made up 0.8 percent of all students and apprentices in upper secondary education in 2017 . The biggest percentage is made up by training candidates in healthcare, childhood and youth development, and building and construction (Markussen et al., 2018). Boys are overrepresented among training candidates, compared to apprentices. Training candidates also have notably lower grades from compulsory education than apprentices and have considerably more absence in lower secondary school. Training practice certificates have yet

1 As of the 2020-2021 school year, new educational programmes, programme areas and subject curricula will be introduced for upper secondary education in Norway. 
to be included in official statistics. As of January 2018, there were only 32 training practice candidates in five counties (Markussen et al., 2018). Both training candidates and training practice certificate candidates have the possibility to continue their training after they pass their individual competence test respective training practice certificate test and work towards a full trade certificate. However, the figures show that very few training candidates continue their training and achieve a trade or journeyman's certificate (Markussen et al., 2018). There are no national figures at present showing the transition to a regular pathway for training practice certificate candidates, and the figures from individual counties show different results (Høst, 2016; Markussen, 2014). With respect to the transition to the labour market, research shows that both training candidates and training practice certificate candidates are in a worse position than young people with a trade or journeyman's certificate, but in a considerably better position than young people who have dropped out (Markussen, 2014).

The percentage of a year group who end up with documented partial competence is 2.1 percent (SSB, 2018a). However, documented partial competence is not included in the completion rate statistics. In Norway, only those who achieve a trade- or journeyman's certificate or a university admissions certification are considered to have completed upper secondary education (SSB, 2018b).

\subsection{Sweden}

In Sweden, both general education and vocational upper secondary programmes have admission requirements based on the grades from compulsory education. There are four introduction programmes at upper secondary level for students who do not pass all the required subjects at lower secondary school. These programmes were introduced in the Upper Secondary Reform of $2011^{2}$ (Education Act, SFS, 2010: 800), which replaced the individual programme introduced in 1993. Introduction programmes aim to facilitate access to and participation in a national education programme or transition into employment. They do not lead to graduation (Skolverket, 2014).

The introduction programmes have no nationally defined structure, curriculum or length. The Swedish Education Act encourages local variation that enables education to be adapted to students with different needs. After having assessed the student's needs, schools are tasked with developing an individual study plan, which defines the objective, length and content of the education. The four introduction programmes have different target groups, e.g. students who lack approved grades in a few subjects, students who want to start working or newly arrived immigrants who primarily need to learn Swedish. Depending on the programme and the students' needs, the programmes generally have a duration of one to three years (Skolverket, 2014). Students who do not wish to or have the opportunity to take a national programme,

2 Until 1 July 2019 there were five different introduction programmes. 
can take VET under the introduction programme "vocational introduction". This education is also individually adapted and follows an individual study plan: The education can include whole or parts of VET programmes included in national programmes, as well as compulsory education subjects that the student lacks. The education must also include practical training (Henning Loeb, 2014). At most schools, this education takes three years (Statens offentlige utredningar, 2016).

Increased immigration and higher admission requirements to national programmes have led to a continuous increase in the percentage of young people starting an introduction programme: For the school year 2016/2017, the percentage of students in the first year of an introduction programme was 24.8 percent (Skolverket, 2017). Compared to national upper secondary education programmes, students with foreign backgrounds, boys, students whose parents have a low level of education and students with poor grades from compulsory education are overrepresented in the introduction programmes (Statens offentlige utredningar, 2016).

Five years after the start-up of the introduction programmes, 19.6 percent of the students had completed upper secondary education and completed a national programme (Skolverket, 2018). In addition to these students, a further 7.9 percent had gained a study certificate - a certificate for students who have completed a national programme, but who have not met the requirements of completion of upper secondary school (Skolverket, 2018). Some students also start working. Around 25 percent of the students who took "vocational introduction" were in work one year after they completed the programme. However, the largest group (41\%) were unemployed (SCB, 2014). The percentage who go on to take national programmes and complete upper secondary education after the introduction programme was lower than expected after the reform. The Swedish Ministry of Education and Research emphasises that the introduction programmes are an important means of encouraging more young people to complete upper secondary education. Measures are therefore being planned to improve these programmes (Utbildningsdepartementet, 2018).

\subsection{Switzerland}

In Switzerland, a two-year apprenticeship was established in 2002 aimed at increasing the employability of low-achieving school leavers. The educational pathway follows standardised training plans and concludes with a standardised certificate (Federal VET Certificate), and it replaces a previously individualised educational pathway. Despite standardised training plans and final tests, the pathway shall also take the individual abilities of the apprentices into account. The goal is for as many young people as possible to complete upper secondary education. As well as standardised qualification requirements, the apprentices' individual rights to support measures are also defined, which do not only include school-related aspects, but 
all aspects of relevance to education in the learner's environment (Vocational Training Order, Swiss Confederation, 2003, art. 10, par. 5). The structure of two-year apprenticeships is similar to three-year and four-year apprenticeships with a combination of company-based and school-based components (Wettstein et al., 2017). However, two-year apprenticeships are less demanding regarding complexity and the apprentices' autonomy than three-year and four-year apprenticeships. According to the responsible ministry, the target group for twoyear apprenticeship is "particularly practically gifted young people and adults" (SBFI, 2014, p. 4). Apprentices in two-year programme come almost exclusively from lower levels of lower secondary school or from classes with adapted curricula, i.e. classes with students who require special education facilitation or newly arrived immigrant youths (BFS, 2016). Compared with the three-year and four-year apprenticeships, young people with minority backgrounds and young people whose parents have a low level of education are over-represented in the two-year apprenticeships (Fitzli, 2017).

Around 57 two-year programmes have been introduced in almost all industries up until 2017, and the number of apprenticeship contracts has increased each year. The two-year apprenticeships in sales and construction is particularly popular. In 2016, the Federal VET Certificates made up around nine percent of all VET certificates (Kammermann, 2017). This corresponds to around six percent of the year group (BFS, 2018a). The trade associations decide whether this type of competence is needed in the labour market. The two-year apprenticeships have their own vocational titles (Kammermann, 2017).

95 percent of the apprentices who take the final test pass it, around 75 percent within the nominal length of study of two years. Apprentices who do not pass the final test receive an individual attestation of competences (Scharnhorst \& Kammermann, 2017). Those who complete may progress to three-year or four-year apprenticeships. On average, about a third do so across all professions (BFS, 2018b). The opposite perspective is also useful: Around 15 percent of the young people taking the two-year pathway had left a three-year or four-year programme (Fitzli, 2017). Regarding the transition to the labour market, research shows that labour market entry is more difficult and takes more time after a two-year apprenticeship than after a three-year or four-year apprenticeship. However, these differences become smaller with increasing observation time. Two to four years after completion of a two-year apprenticeship, around 85 percent are either in employment or further education (Fitzli, 2017).

\section{Discussion}

The study has described seven different training schemes for youth at risk in Austria, Norway, Sweden and Switzerland. Based on the programmes' structure and objective, the study distinguishes between four different education and training models for youth at risk: individually adapted, short-track, prolonged and preparatory programmes (see table 2). The intro- 
duction programme in Sweden has a twofold objective - in addition to preparing students for a national programme on upper secondary level it also aims to prepare them for the labour market - and is therefore assigned to two different education and training models. The four identified education and training models are described in the following subchapters.

Table 2: Four education and training models for youth at risk in Austria, Norway, Sweden and Switzerland

\begin{tabular}{|c|c|c|c|c|}
\hline & Norway & Switzerland & Sweden & Austria \\
\hline $\begin{array}{l}\text { Individually } \\
\text { adapted } \\
\text { programmes }\end{array}$ & $\begin{array}{l}\text { Training } \\
\text { candidate scheme }\end{array}$ & & $\begin{array}{l}\text { Vocational } \\
\text { introduction pro- } \\
\text { gramme } \\
\text { (targeting the labour } \\
\text { market) }\end{array}$ & $\begin{array}{l}\text { Partial } \\
\text { qualification scheme }\end{array}$ \\
\hline $\begin{array}{l}\text { Short-track } \\
\text { programmes }\end{array}$ & $\begin{array}{l}\text { Training practice } \\
\text { certificate scheme }\end{array}$ & $\begin{array}{l}\text { Two-year } \\
\text { apprenticeships } \\
\text { with Federal VET } \\
\text { Certificate }\end{array}$ & & \\
\hline $\begin{array}{l}\text { Prolonged } \\
\text { programmes }\end{array}$ & & & & $\begin{array}{l}\text { Prolonged apprenti- } \\
\text { ceship scheme }\end{array}$ \\
\hline $\begin{array}{l}\text { Preparatory } \\
\text { programmes }\end{array}$ & & & $\begin{array}{l}\text { Introduction pro- } \\
\text { grammes (targeting } \\
\text { upper secondary } \\
\text { level) }\end{array}$ & \\
\hline
\end{tabular}

\subsection{Individually adapted programmes}

Individually adapted programmes neither have a defined length nor content, the training in its entirety is adapted to the students' abilities, needs and wishes. No standardised competence requirements therefore have to be followed, and the final test is also individually adapted in accordance with the content of an individual training plan or training contract. After passing the final test, the students receive a vocational training certificate showing the competence demonstrated by the student. The programme is linked to a 'regular' upper secondary programme, and the competence goals selected will be made up by some of the competence goals for the corresponding programme to the full vocational qualification. The objective is to prepare the student for working life. This type of training model is found in Norway (training candidate scheme) and Austria (partial qualification scheme). The introduction programme "vocational introduction" in Sweden is also an individually adapted programme that can have a labour market focus. The examples in Norway, Austria and Sweden show that individually adapted training programmes can take place in a school, workshop or in a training company. It depends on the training tradition in the country in question, and the training is adapted to the student's abilities and needs within the given framework. This also applies to the length of training, which is based on the training content and planned competence requirements. This can vary from just a few competence requirements 
to almost the entire curriculum for a pathway to a full vocational qualification. This is the major strength of an individually adapted programme: There are few guidelines, and it is the student's needs and abilities that form the basis for and have to be taken into account in the training. This type of approach provides a good basis for getting students through upper secondary education, who otherwise would not have been able to take and complete upper secondary level education.

One of the challenges of individually adapted programmes is ensuring they are recognised by youths, parents, teachers, advisers and, not least, employers. In Switzerland, individually adapted pathways were replaced in 2002 by standardised two-year programmes. The individualised training scheme was not attractive enough to youths and their parents, and the level of recognition in the labour market was considered to be too low (Kammermann, 2017). This is also a major challenge in Norway. The introduction of a type of formal competence at a lower level than a full vocational qualification and the introduction of the training candidate scheme were not welcomed by the labour market. Seventeen years after the scheme became statutory, the number of training candidates in this pathway - in relation to the number of students who drop out of upper secondary education due to inadequate performance - is still very low. The scheme does not thus appear to be an attractive option among youths and parents (Markussen et al., 2018). Labour market prospects are vital to the support that individually adapted programmes enjoy among youths, parents, teachers, advisers and in the labour market. The transition to the labour market appears to be more difficult for those who have completed an individually adapted pathway than for those with a full vocational qualification, in both Norway and Austria. The majority are nonetheless in employment, in both Norway and Austria, three years after completion (Dornmayr, 2017; Markussen, 2014). This shows that this type of certificate has value in the labour market. In the examples studied, these pathways do not qualify as completed and passed upper secondary education. Young people who have completed this type of upper secondary education are thus not included in national and international completion rate statistics but end up in the category "early leaver from education and training".

\subsection{Short-track programmes}

Short-track programmes are both shorter and at a lower level than a 'regular' vocational programme. Unlike individually adapted programmes, short-track pathways follow nationally or locally defined curricula. This means that there are standardised competence requirements, and that the training concludes with a standardised test. Usually there will be a corresponding programme that leads to a certificate at a higher level. Like regular vocational pathways, the objective of short-track programmes is also to prepare young people for the labour market. In the current sample, the study found short-track programmes in Norway (training 
practice certificate scheme) and in Switzerland (two-year apprenticeships with Federal VET Certificate). These pathways have a duration of two years in both Norway and Switzerland.

In Norway, the county authorities, together with local business and industry, decides which education programmes are to offer a training practice certificate scheme (Utdanningsdirektoratet, 2017). The county authorities are obliged to offer a training practice certificate scheme in at least one VET programme. There are thus local curricula, rather than a national curriculum, which means that the schemes vary depending on where the students live. There is no overview of the training practice certificate schemes available in Norway. As of January 2018, there were only 32 training practice candidates (Markussen et al., 2018). In Switzerland, trade associations are responsible for assessing the need for this type of competence in the labour market, and whether to introduce a two-year apprenticeship. With around 57 vocations covering almost all industries, young people have a wide range of two-year options to choose from. The two-year pathway in Switzerland also has its own professional titles (Kammermann, 2017). In Norway, professional titles have yet to be established for training practice certificates, but this is under debate (Markussen et al., 2018).

In Switzerland, two-year apprenticeships appear to be an important option for young people who are unable to complete a three- or four-year apprenticeship, and those who need a lower threshold into VET to continue on a 'regular' pathway. There is satisfactory recognition of this programme in the labour market, and the majority of those with this type of qualification are in work (Fitzli, 2017). Around six percent of a year group complete a two-year apprenticeship (BFS, 2018a), and are deemed to have "completed and passed" upper secondary education.

In Norway, there has been little research on the training practice certificate scheme since it was first introduced in 2016. The evaluation of a trial period in three counties concluded however that the scheme was "a very successful measure to reduce dropout" (Høst, 2016, p. 196). These schemes are not currently considered to be equivalent to completed upper secondary education, but this has recently been placed on the agenda and has support among the parties in the labour market (Markussen et al., 2018).

\subsection{Prolonged programmes}

Prolonged programmes lead to the same total competence as 'regular' upper secondary education. The apprentices in these pathways follow the same competence goals and take the same final test at the end of the training as apprentices in a 'regular' pathway. They have more time however, and, in the case of Austria, they also receive guidance from a "vocational assistant". In Austria, only young people who meet certain special needs criteria are entitled to this type of training. Nonetheless, the aim is for these young people to take a full trade or journeyman's certificate. This apparent balancing act is addressed by extending the period of 
training and close follow-up. It is thus not surprising that this pathway has a higher dropout rate than 'regular' apprenticeships. Those who complete and pass the training however have good job prospects. The scheme is therefore considered a success in Austria. Particular emphasis is given to the fact that it has an 'anti-discriminatory' effect (Dornmayr, 2017, p. 30) by giving youth at risk more time, rather than less time. It should also be mentioned that other countries are considering this option. Students and apprentices have the right to prolonged training in both Norway and in Switzerland (Section 3-1 fifth paragraph and Section 5 of the Norwegian Education Act; Vocational Training Act, Swiss Confederation, 2002, art. 18, par. 1). This is based however on individual decisions in both Norway and Switzerland.

\subsection{Preparatory programmes}

Unlike the three other training schemes outlined above, preparatory programmes do not aim to prepare young people directly for the labour market, but for regular upper secondary education. Students who, for various reasons, are not ready for regular upper secondary education, receive more training to reach the level required by upper secondary education. In the current sample, the study found a preparatory programme in Sweden: Four introduction programmes are available that aim to enable students to start a national upper secondary programme $e^{3}$. The introduction programmes give students the opportunity to take a number of courses and improve their grades, and students complete the courses they need based on an individual study plan. The programmes also have different focuses and target different target groups. These target groups reflect the heterogeneity of students who lack qualifications for national upper secondary programmes. A number of countries have various transitional options to make the transition from lower to upper secondary education easier (for Switzerland, see e.g. 'Transitional options' in Wettstein et al., 2017). Unlike these, the introduction programme in Sweden is a part of upper secondary education.

\section{Conclusion}

The aim of this article was to identify education and training models for youth at risk of dropping out of upper secondary education without achieving qualifications at this level. For this purpose, the study selected four countries with different educational traditions at upper secondary level - Austria, Norway, Sweden and Switzerland - and compared the education and training programmes for youth at risk in these countries. The background for the study is an increased focus on the completion of upper secondary education in recent years and, at

3 The introduction programme 'vocational introduction' aimed at the labour market is not considered preparatory in the present classification, but an individually adapted programme (see individually adapted programmes). 
the same time, an increasingly heterogeneous VET target group. VET is thus required to have different goals, which are sometimes contradictory. On the one hand, VET must meet labour market requirements of efficiency, quality and competence, and ensure it is related to higher education and lifelong learning. On the other hand, however, VET must include young people with different educational performances and social backgrounds to a greater extent than previously (Larsen \& Persson Thunqvist, 2018). When the target group changes, the education system's structures must be adapted accordingly. The four countries studied have different approaches to adapting upper secondary training schemes for youth at risk. The study distinguishes between two strategies at an overriding level: While one strategy aims to encourage and support students and apprentices so that they can conclude their education with an 'regular' vocational qualification or a university admissions certificate, the other strategy aims to adapt the training to a level lower than a 'regular' vocational qualification. Some young people will not be able to complete and pass 'regular' upper secondary education, even with more preparation, time or follow-up and guidance. In all the countries included in this study, these young people have the opportunity to conclude their education with a certificate at a level lower than 'regular' upper secondary education.

Based on this study, it is not possible to determine which of the four identified education and training models for youth at risk is best suited to including vulnerable youth in upper secondary education and the labour market. This issue will require longitudinal data. The comparison of the training programmes for youth at risk of dropping out in Austria, Norway, Sweden and Switzerland, however, identifies some differences between these countries, which are assumed to be relevant in terms of the inclusion of disadvantaged youth. Three of them are explained in the following. Firstly, it is obvious that the percentage of young people in programmes tailored to the needs of youth at risk varies widely between the four countries studied (see table 1). This is related to the different admission requirements to upper secondary education: In Sweden, the admission requirements to national programmes exclude almost a fourth of any year group, such that the percentage of students in preparatory introduction programmes is very high. In Norway, on the other hand, all young people have a statutory right to a place in upper secondary education (Nyen \& Tønder, 2015), and the percentage of young people in training candidate and training practice certificate schemes is very low. In Austria and Switzerland, the apprenticeship market regulates access to vocational education and training and thus has a decisive influence on the criteria for the allocation of training places.

These countries thus regulate access to upper secondary education in very different ways, and, for disadvantaged youth in particular, these regulations can be very decisive. The second point concerns the different importance assigned to VET at upper secondary level in the countries studied. This can be seen, among other things, in the percentage of young people in VET programmes at upper secondary level and the percentage of students in combined 
school and work-based VET (see table 1). Since education policy emphasises the importance of VET in getting early school leavers and disadvantaged youth into education and employment, it is natural to look at the position of VET in these countries. There is a lot of evidence that indicates that a well-developed VET system has a positive effect on the inclusion of potentially at-risk youth (e.g. De Witte et al., 2013; Lamb, 2011a; Lavrijsen \& Nicaise, 2015). Various actors also emphasise the positive significance of work-based learning on motivation and professional identity (Cedefop, 2016; OECD, 2010). This is not necessarily a question of whether VET is organised as apprenticeship training or a school-based programme. A short, structured workplace learning component in classroom-based VET has for example in Australia been associated with higher school completion rates and better employment transitions (Polidano \& Tabasso, 2014).

Finally, the last difference to be highlighted concerns the recognition of training programmes for youth at risk. To date, Switzerland is the only country in the current sample that issues certificates after a two-year apprenticeship as completed and passed upper secondary education. This practice contributes to high completion rates in Switzerland (see table 1). If training schemes for youth at risk are to attract vulnerable young people, it is vital that they lead to recognition in society and that the certificate is valued in the labour market. Furthermore, research from Austria, Norway and Switzerland shows that young adults with a vocational training certificate at a lower level than a 'regular' vocational qualification are in a better position in the labour market than people without any upper secondary education (Dornmayr, 2017; Fitzli, 2017; Markussen, 2014). Further research must include longitudinal data and investigate which type of education and training is best suited to including youth at risk in upper secondary education and the labour market. Furthermore, further research must extend the work to a larger geographical area. Systematic mapping of the training schemes available to youth at risk is particularly important for countries with a high dropout rate, which often have 'weak VET systems and lack attractive non-academic programmes' (European Commission, 2014, p. 13). VET plays a key role with respect to securing work for youth at risk and measures to ensure more of them complete upper secondary education and make good transitions to working life.

\section{References}

Alexander, K. L., Entwisle, D. R., \& Kabbani, N. (2001). The Dropout Process in Life Course Perspective: Early Risk Factors at Home and School. Teachers College Record, 103(5), 760-822.

Archambault, I., Janosz, M., Dupéré, V., Brault, M.-C., \& Mc Andrew, M. (2017). Individual, Social, and Family Factors Associated with High School Dropout among Low-SES Youth: Differential Effects as a Function of Immigrant Status. British Journal of Educational Psychology, 87(3), 456-477. https://doi.org/10.1111/bjep.12159 
Berufsausbildungsgesetz (BAG). Retrieved from: https://www.jusline.at/gesetz/bag/paragraf/8b

BFS (2016). Längsschnittanalysen im Bildungsbereich. Der Übergang am Ende der obligatorischen Schule. Ausgabe 2016. Bundesamt für Statistik.

BFS (2018a). Quote der Erstabschlüsse auf der Sekundarstufe II und Maturitätsquote. Bundesamt für Statistik.

BFS (2018b). Übergänge nach Abschluss der Sekundarstufe II und Integration in den Arbeitsmarkt. Längsschnittanalysen im Bildungsbereich, Ausgabe 2018. Neuchâtel: Bundesamt für Statistik.

Bowen, G. A. (2009). Document Analysis as a Qualitative Research Method. Qualitative Research Journal, 9(2), 27-40. https://doi.org/10.3316/QRJ0902027

Busemeyer, M. R., \& Trampusch, C. (2012). The Comparative Political Economy of Collective Skill Formation. In M. Busemeyer, \& C. Trampusch (Eds.), The Political Economy of Collective Skill Formation (pp. 3-38). Oxford University Press.

Cedefop (2016). Leaving education early: putting vocational education and training centre stage. Volume I: Investigating causes and extent. Cedefop Publications.

De Ridder, K. A. A., Pape, K., Johnsen, R., Holmen, T. L., Westin, S., \& Bjørngaard, J. H. (2013). Adolescent Health and High School Dropout: A Prospective Cohort Study of 9000 Norwegian Adolescents (The Young-HUNT). PLoS One, 8(9), 1-7. https://doi.org/10.1371/journal.pone.0074954

De Witte, K., Nicaise, I., Lavrijsen, J., Van Landeghem, G., Lamote, C., \& Van Damme, J. (2013). The Impact of Institutional Context, Education and Labour Market Policies on Early School Leaving: A Comparative Analysis of EU Countries. European Journal of Education, 48(3), 331-345. https:// doi.org/10.1111/ejed.12034

Dornmayr, H. (2017). Ausbildungen gem. \$ 8b BAG (Lehrzeitverlängerung und Teilqualifizierung) für benachteiligte Jugendliche in Österreich. In M. Becker, M. Kammermann, G. Spöttl, \& L. Balzer (Eds.), Ausbildung zum Beruf. Internationaler Vergleich der berufsförmigen Ausbildungskonzepte für benachteiligte Jugendliche (pp. 29-43). Peter Lang.

Dornmayr, H., Löffler, R., \& Litschel, V. (2017). Evaluierung der Lehrstellenförderung des AMS Österreich. Endbericht. ibw/öibf.

European Commission (2014). Tackling Early Leaving from Education and Training in Europe: Strategies, Policies and Measures. Eurydice and Cedefop Report. Publications Office of the European Union.

European Parliament (2011). Reducing Early School Leaving in the EU. European Parliament.

Finn, J. D. (1989). Withdrawing From School. Review of Educational Research, 59(2), 117-142. https:// doi.org/10.3102/00346543059002117

Fitzli, D. (2017). Evaluation der Arbeitsmarktsituation und Weiterbildungsperspektive von Absolventen und Absolventinnen mit Eidgenössischem Berufsattest (EBA). In M. Becker, M. Kammermann, G. Spöttl, \& L. Balzer (Eds.), Ausbildung zum Beruf. Internationaler Vergleich der berufsförmigen Ausbildungskonzepte für benachteiligte Jugendliche (pp. 219-243). Peter Lang.

Heckl, E., Dörflinger, C., Dorr, A., \& Klimmer, S. (2008). Evaluierung der integrativen Berufsausbildung (IBA). Endbericht. Austrian Institute for SME Research.

Henning Loeb, I. (2014). Graden av individanpassning i gymnasieskolans introduktionsprogram yrkesintroduktion. En fallstudie på uppdrag av Skolverket hösten 2014. Institutionen för pedagogik och specialpedagogik.

Hoffman, N. (2011). Schooling in the Workplace. How Six of the World's Best Vocational Education Systems Prepare Young People for Jobs and Life. Harvard Education Press. 
Hupka-Brunner, S., Sacchi, S., \& Stalder, B. E. (2010). Social origin and access to upper secondary education in Switzerland: A comparison of company-based apprenticeship and exclusively schoolbased programmes. Swiss Journal of Sociology, 36(1), 11-31. https://doi.org/10.5167/uzh-43185

Høst, H. (2016). Praksisbrev i arbeidslivet - et vellykket tiltak mot frafall. In K. Reegård, \& J. Rogstad (Eds.), De Frafalne. Om frafall i videregående oppleering - hvem er de, hva vil de og hva kan gjøres? (pp. 173-198). Gyldendal akademisk.

Imdorf, C. (2017). Understanding discrimination in hiring apprentices: how training companies use ethnicity to avoid organisational trouble. Journal of Vocational Education \& Training, 69(3), 405423. https://doi.org/10.1080/13636820.2016.1278397

Janosz, M., Bisset, S. L., Pagani, L. S., \& Levin, B. (2011). Educational Systems and School Dropout in Canada. In S. Lamb, E. Markussen, R. Teese, N. Sandberg, \& J. Polesel (Eds.), School Dropout and Completion: International Comparative Studies in Theory and Policy (pp. 295-320). Springer.

Jørgensen, C. H. (2015). Some boys' problems in education - what is the role of VET? Journal of Vocational Education \& Training, 67(1), 62-77. https://doi.org/10.1080/13636820.2014.917694

Jørgensen, C. H. (2018). Vocational education and training in the Nordic countries: different systems and common challenges. In C. H. Jørgensen, O. J. Olsen, \& D. Persson Thunqvist (Eds.), Vocational education in the Nordic countries. Learning from diversity (pp. 1-28). Routledge.

Kammermann, M. (2017). Die Entwicklung der zweijährigen beruflichen Grundbildungen mit Eidgenössischem Berufsattest (EBA) in der Schweiz. In M. Becker, M. Kammermann, G. Spöttl, \& L. Balzer (Eds.), Ausbildung zum Beruf. Internationaler Vergleich der berufsförmigen Ausbildungskonzepte für benachteiligte Jugendliche (pp. 11-28). Peter Lang.

Korp, H. (2012). 'I think I would have learnt more if they had tried to teach us more' - performativity, learning and identities in a Swedish Transport Programme. Ethnography and Education, 7(1), 77-92. https://doi.org/10.1080/17457823.2012.661589

Lamb, S. (2011a). Pathways to School Completion: An International Comparison. In S. Lamb, E. Markussen, R. Teese, N. Sandberg, \& J. Polesel (Eds.), School Dropout and Completion: International Comparative Studies in Theory and Policy (pp. 21-73). Springer.

Lamb, S. (2011b). School Dropout and Completion in Australia. In S. Lamb, E. Markussen, R. Teese, N. Sandberg, \& J. Polesel (Eds.), School Dropout and Completion: International Comparative Studies in Theory and Policy (pp. 321-339). Springer.

Lamb, S. (2011c). School Dropout and Inequality. In S. Lamb, E. Markussen, R. Teese, N. Sandberg, \& J. Polesel (Eds.), School Dropout and Completion: International Comparative Studies in Theory and Policy (pp. 369-390). Springer.

Lamb, S., \& Markussen, E. (2011). School Dropout and Completion: An International Perspective. In S. Lamb, E. Markussen, R. Teese, N. Sandberg, \& J. Polesel (Eds.), School Dropout and Completion: International Comparative Studies in Theory and Policy (pp. 1-18). Springer.

Larsen, L., \& Persson Thunqvist, D. (2018). Balancing the esteem of vocational education and social inclusion in four Nordic countries. In C. H. Jørgensen, O. J. Olsen, \& D. Persson Thunqvist (Eds.), Vocational education in the Nordic countries. Learning from diversity (pp. 74-94). Routledge.

Lavrijsen, J., \& Nicaise, I. (2015). Social Inequalities in Early School Leaving: The Role of Educational Institutions and the Socioeconomic Context. European Education, 47(4), 295-310. https://doi.org /10.1080/10564934.2015.1098265

Markussen, E. (2011). Frafall i videregående opplæring: i Norge og andre land. Bedre Skole, 2011(1), $10-15$. 
Markussen, E. (2014). Jobb å få? Om overgang til arbeid for personer som har vart i løp mot planlagt grunnkompetanse $i$ Akershus i årene 2009-2012. NIFU.

Markussen, E., Frøseth, M. W., Lødding, B., \& Sandberg, N. (2008). Bortvalg og kompetanse: Gjennomføring, bortvalg og kompetanseoppnåelse $i$ videregående opploering blant 9749 ungdommer som gikk ut av grunnskolen på Østlandet våren 2002: Hovedfunn, konklusjoner og implikasjoner fem år etter. NIFU STEP.

Markussen, E., Grøgaard, J. B., \& Hjetland, H. N. (2018). Jeg vet ikke hva alternativet skulle vort». Evaluering av loerekandidatordningen og av ordningen med tilskudd til opploering av loerlinger, praksisbrevkandidater og loerekandidater med sarskilte behov. NIFU.

Nyen, T., \& Tønder, A. H. (2015). Cooperation and Reform in Vocational Education and Training. In F. Engelstad, \& A. Hagelund (Eds.), Cooperation and Conflict the Nordic Way. Work, Welfare, and Institutional Change in Scandinavia (pp. 201-218). De Gruyter Open.

OECD (2010). Learning for Jobs. OECD Publishing.

OECD (2013). PISA 2012 Results: Excellence through Equity. Giving Every Student the Chance to Succeed. Volume II. OECD Publishing.

OECD (2018a). Education at a Glance 2018. OECD Indicators. OECD.

OECD (2018b). Seven Questions about Apprenticeships: Answers from International Experience. OECD.

Opplæringslova. Lov om grunnskolen og den vidaregåande opplæringa. Sist endret i LOV-2018-0622-56, med virkning fra 1.8.2018. Retrieved from: https://lovdata.no/dokument/NL/lov/1998-07$17-61$

Polidano, C., \& Tabasso, D. (2014). Making it real: The benefits of workplace learning in upper-secondary vocational education and training courses. Economics of Education Review, 42, 130-146. https://doi.org/10.1016/j.econedurev.2014.06.003

Quiroga, C. V., Janosz, M., Bisset, S., \& Morin, A. J. S. (2013). Early Adolescent Depression Symptoms and School Dropout: Mediating Processes Involving Self-Reported Academic Competence and Achievement. Journal of Educational Psychology, 105(2), 552-560. https://doi.org/10.1037/ a0031524

Rinne, R., \& Järvinen, T. (2011). Dropout and Completion in Upper Secondary Education in Finland. In S. Lamb, E. Markussen, R. Teese, N. Sandberg, \& J. Polesel (Eds.), School Dropout and Completion: International Comparative Studies in Theory and Policy (pp. 215-232). Springer.

Rumberger, R. W. (2011). Dropping Out: Why Students Drop Out of High School and What Can Be Done About It. Harvard University Press.

Rumberger, R. W., \& Rotermund, S. (2012). The Relationship Between Engagement and High School Dropout. In S. L. Christenson, A. L. Reschly, \& C. Wylie (Eds.), Handbook of Research on Student Engagement (pp. 491-513). Springer.

SBFI (2014). Zweijährige berufliche Grundbildung mit eidgenössischem Berufsattest. Leitfaden (2nd ed.). Staatssekretariat für Bildung, Forschung und Innovation.

SCB (2014). Inträdet på arbetsmarknaden efter gymnasieskolan. Statistiska centralbyrån.

Scharnhorst, U., \& Kammermann, M. (2017). Wie inklusiv ist die zweijährige berufliche Grundbildung in der Schweiz? In M. Becker, M. Kammermann, G. Spöttl, \& L. Balzer (Eds.), Ausbildung zum Beruf. Internationaler Vergleich der berufsförmigen Ausbildungskonzepte für benachteiligte Jugendliche (pp. 245-286). Peter Lang.

Scott, J. (1990). A matter of record: Documentary sources in social research. Polity Press.

SFS (2010). Education Act. SFS 2010: 800. 
Skolverket (2014). Introduktionsprogram. Skolverket.

Skolverket (2017). Elever i gymnasieskolan läsåret 2016/17. Skolverket.

Skolverket (2018). Uppföljning av gymnasieskolan 2018. Skolverket.

Solga, H., \& Kohlrausch, B. (2013). How Low-achieving German Youth Beat the Odds and Gain Access to Vocational Training-Insights from Within-Group Variation. European Sociological Review, 29(5), 1068-1082. https://doi.org/10.1093/esr/jcs083

SSB (2018a, 5. januar). Gjennomføring i videregående øker, særlig i Finnmark. Retrieved from: https:// www.ssb.no/utdanning/artikler-og-publikasjoner/gjennomforing-i-videregaende-oker-saerlig-ifinnmark

SSB (2018b, 22. may). Gjennomføring i videregående opplæring, 2011-2016. Retrieved from: https:// www.ssb.no/utdanning/statistikker/vgogjen/aar/2017-06-01?fane=om

Statens offentlige utredningar (2016). En gymnasieutbildning för alla - åtgärder för att alla unga ska påbörja och fullfölja en gymnasieutbildning. Del 1. Stockholm: Regeringskansliets förvaltningsavdelning.

Swiss Confederation (2003). Vocational Training Order. Verordnung über die Berufsbildung vom 19. November 2003. Bundeskanzlei.

Swiss Confederation (2002). Vocational Training Act. Bundesgesetz über die Berufsbildung vom 13. Dezember 2002. Bundeskanzlei.

Traag, T., \& van der Velden, R. K. W. (2011). Early school-leaving in the Netherlands: the role of family resources, school composition and background characteristics in early school-leaving in lower secondary education. Irish Educational Studies, 30(1), 45-62. https://doi.org/10.1080/03323315.2 011.535975

Utbildningsdepartementet (2018). Lagrådsremiss. En gymnasieutbildning för alla. Utbildningsdepartementet.

Utdanningsdirektoratet (2015). Lærekandidatordning. Utdanningsdirektoratet.

Utdanningsdirektoratet (2017). Praksisbrev. Utdanningsdirektoratet.

Vilbli (2018, January 11). Grunnkompetanse. Retrieved from: https://www.vilbli.no/nb/nb/no/ grunnkompetanse/a/025415

Wettstein, E., Schmid, E., \& Gonon, P. (2017). Swiss Vocational and Professional Education and Training (VPET). Forms, System, Stakeholders. hep.

\section{Acknowledgements}

The author would like to thank Helmut Dornmayr and Ingrid Henning Loeb for the helpful information they provided on the educational programmes in their countries as well as Marlise Kammermann and two anonymous reviewers for valuable comments.

\section{Biographical Notes}

Evi Schmid, $\mathrm{PhD}$, is an associate professor at the Department of Vocational Teacher Education at OsloMet - Oslo Metropolitan University, Norway. Her research interests include school-to-work transitions, dropout from VET, social inclusion and education policy. 